\title{
ЭКСПОРТ ХВОЙНЫХ ПИЛОМАТЕРИАЛОВ ИЗ РОССИИ в японию
}

\author{
А. В. Новиков \\ Байкальский государственный университет, г. Иркутск, Российская Федерация
}

Информация о статье

Дата поступления

17 января 2018 г.

Дата принятия к печати

21 мая 2018 г

Дата онлайн-размещения 8 июня 2018 г.

\section{Ключевые слова}

Экспорт; пиломатериалы; таруки; Иркутская область; Россия; Япония

\begin{abstract}
Аннотация
Япония является основным покупателем строганой сосны и ели из Иркутской области (около 68 и 34 \% объема поставок в 2017 г. соответственно). Емкость рынка пиломатериалов Японии оценива-

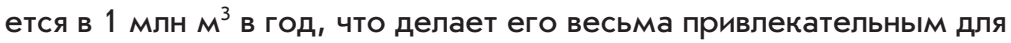
поставщиков пиломатериалов. Основной поток поставок из России приходится на Иркутскую область (до 40 \% всех строганых и профилированных пиломатериалов) - это экспорт строганой сосны в Японию. В статье проведена оценка экспорта пиломатериалов из России в Японию, рассмотрена динамика экспорта хвойных пиломатериалов крупнейшими российскими компаниями в Японию, исследовано потребление древесины в компонентах традиционного японского дома, проанализировано начатое жилищное строительство по типам конструкций в Японии, представлены цены на строганый брусок, а также курс рубля к доллару и курс иены к доллару.
\end{abstract}

\section{SOFTWOOD LUMBER EXPORTS FROM RUSSIA TO JAPAN}

\section{Alexander V. Novikov \\ Baikal State University, Irkutsk, the Russian Federation}

\section{Article info}

Received

January 17, 2018

Accepted

May 21, 2018

Available online

June 8, 2018

\section{Keywords}

Exports; sawnwood; taruki; Irkutsk region; Russia; Japan

\begin{abstract}
Japan is the main buyer of planed pine and spruce from the Irkutsk region (about 68 and $34 \%$ of shipments in 2017, respectively). The capacity of the lumber market of Japan is estimated at 1 million cubic meters per year, which makes it very attractive for suppliers of lumber. The main flow of supplies from Russia falls on the Irkutsk region (up to $40 \%$ of all planed and profiled timber), this is the export of sawn pine to Japan. The author of the article conducts assessment of timber export from Russia to Japan, analyzes the dynamics of export of coniferous sawn timber of the largest Russian companies to Japan, studies consumption of wood in the components of a traditional Japanese house, analyzes the started residential construction by type of constructions in Japan. The price of planed pine and also the rate of exchange of the ruble to the dollar and the yen to the dollar are given.
\end{abstract}

Япония - традиционный импортер высококачественной древесной продукции со строгими требованиями к продуктам из-за высокой специализации конечных потребителей [1, с. 192]. Кроме того, выход на японский рынок - это гарантированный сбыт продукции с возможностью согласования программы заказов на долгосрочный период, что крайне важно для стабильной работы предприятия и планирования производства'.

Однако при всех перспективах выйти на японский рынок достаточно сложно [2,

1 Экспорт из России строганых и профилированных пиломатериалов в 2016 году : аналит. отчет / / Аналитический центр GS Group. 2016. № 1. С. 1-11. c. 32], прежде всего из-за жестких норм и правил, регулирующих качество поставляемой продукции. Импортируемая продукция должна отвечать требованиям японских стандартов JAS (японские сельскохозяйственные стандарты). В них подробно прописаны требования к качеству древесины, а также методы испытаний клеевых соединений для строительного бруса².

Стандарты JAS относятся к разряду наиболее жестких в мире, с более высокими

2 Японские сельскохозяйственные стандарты (Japanese Agricultural Standard of Organic Agricultural Products (JAS)). URL: http://www.fao.org/ docrep/004/Y1669E/y1669e0b.htm. 
требованиями по сравнению с европейскими стандартами. Получение сертификата JAS необходимо как для местных, так и для зарубежных производителей, поставляющих продукцию на японский рынок [3, с. $164 ; 4$, с. 89]. В противном случае отношение к ним будет весьма недоверчивое, а реализация товаров окажется затруднена.

Существуют и другие особенности, которые необходимо учитывать, выходя на японский рынок, например жесткие нормы предельно допустимых концентраций вредных веществ, ограничения на применение материалов, содержащих фрормальдегид. Кроме того, продвижение на японский рынок возможно только через крупные торговые дома.

В Японии строганые пиломатериалы в основном используются для деревянного домостроения. Традиционный японский дом возводится на бетонной платформе и низком ленточном фуундаменте. Нижний (венечный) брус (dobai) кладется непосредственно на фундамент. Балки пола (obiki) крепятся на низких опорах (tsuka) и идут через весь дом, формируя основу для поперечных половых лагов (neda). Эта система формирует первый этаж. Необходимо отметить, что все указанные элементы находятся на уровне земли и, следовательно, могут подвергаться атакам насекомых. Поэтому все элементы дома на высоте до 1 м от земли обрабатываются инсектицидами (главным образом против термитов). Система вертикальных опор дома состоит из главных угловых опорных столбов (toshibashira) и опорных столбов (kudabashira).
Главные опорные столбы проходят через два этажа здания н обычно располагаются по углам дома и посередине стеновых пролетов (если дом длинный). Опорные столбы (kudabashira) располагаются между главными опорами и служат для поэтажной поддержки. Промежуточные стойки (mabashira) не являются несущими элементами стены, диагональная подпорка стены (sujikai) обычно крепится в пазах опорных столбов (kudabashira) и служит для дополнительного упрочнения стены. Поперечные несущие балки (hirakaku) размещаются поверх стен первого этажа, создавая базу для второго этажа и связывая воедино внешние стены дома. Все остальные элементы, применяемые при фоормировании второго этажа здания, аналогичны вышеперечисленным, однако высота стен второго этажа несколько меньше. Для крыши используется стропильная система анкерных балок (hari), расположенных поперек длины дома. Кровельная балка (тоуа) крепится на опорах (koyazuka) и служит основой для укладки стропил (taruki). Стропила прибиваются к коньковой балке (munagi) с одной стороны, к кровельным балкам (mоуа) по скату и внизу к верхней стеновой балке (keta).

Структурные деревянные элементы, используемые при строительстве традиционного японского дома (jikugumi) типа Post and $\mathrm{Beam}^{3}$, представлены на рис. 1.

${ }^{3}$ Post and Beam - технология строительства, использующая каркас из вертикальных и горизонтальных балок, состоящих из обработанных мощных стволов многолетних деревьев.

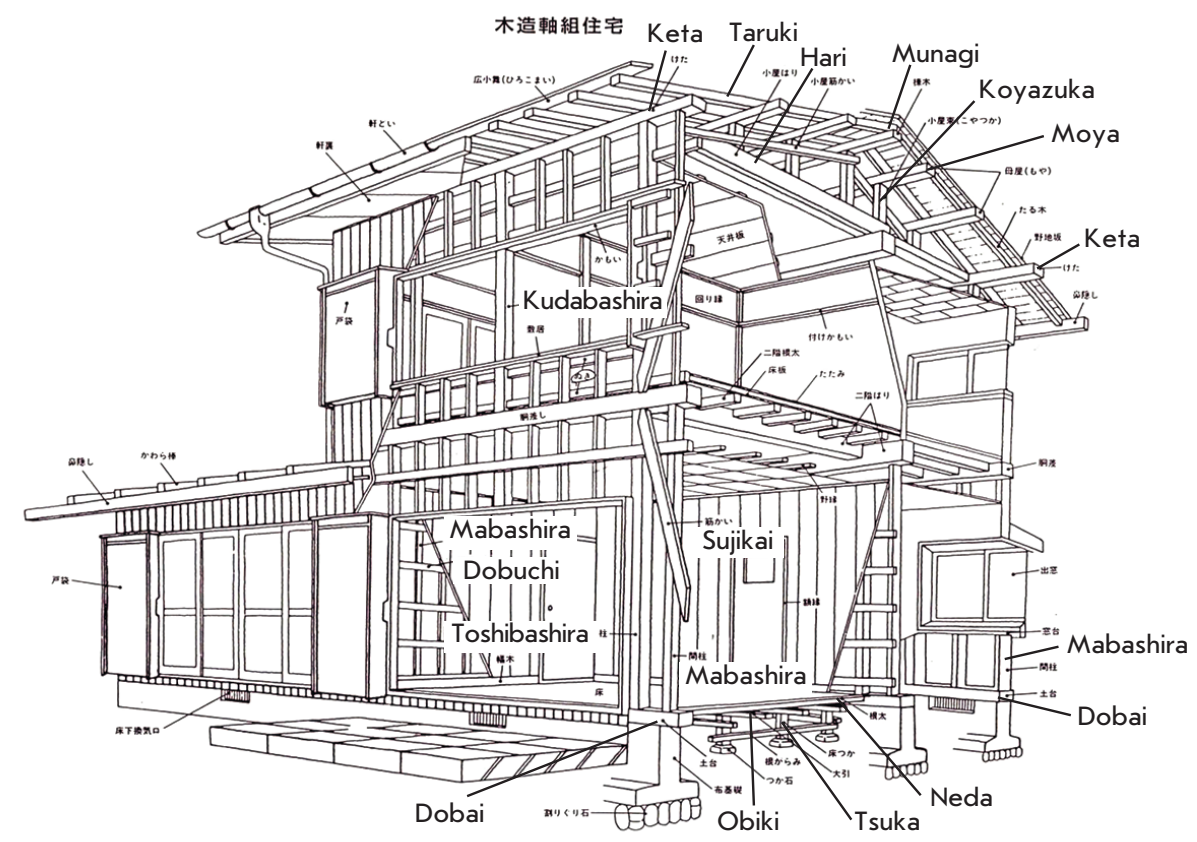

Рис. 1. Структурные деревянные элементы, используемые при строительстве традиционного японского дома типа Post and Beam площадью $100 \mathrm{~m}^{2}$ 
Jikugumi - это традиционный японский дом из столбов и балок, при изготовлении которого все больше применяются материалы из клееного бруса. На этот тип приходится самая большая доля деревянных домов. В строительстве домов jikugumi заняты тысячи очень малых строительных фрирм, поскольку для постройки дома требуется бригада из трех-четырех квалифицированных рабочих.

Примерный объем и спецификация структурных деревянных элементов, используемых при строительстве традиционного японского дома типа Post and Beam

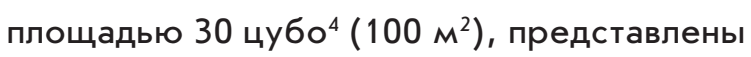
в табл. 1.

С учетом тенденции к увеличению площади дома до 36 цубо $\left(120 \mathrm{M}^{2}\right)$ потребление пиломатериалов также возрастает:

- вертикальные столбы (bashira) - до 80 штук на дом, или 2,6 м;

- горизонтальные балки (hirakaku) - до $6,4 \mathrm{M}^{3}$.

Потребление древесины в компонентах традиционного японского дома представлено на рис. 2.

${ }^{4}$ Цубо, или тсубо (tsubo) - японская мера поверхностей, равная $3,3058 \mathrm{~m}^{2}$.

Примерный объем и спецификация структурных деревянных элементов, используемых при строительстве традиционного японского дома типа Post and Beam площадью $100 \mathrm{~m}^{2}$

\begin{tabular}{|c|c|c|c|c|c|}
\hline $\begin{array}{c}\text { Структур- } \\
\text { ный элемент }\end{array}$ & $\begin{array}{l}\text { Английское } \\
\text { название }\end{array}$ & $\begin{array}{l}\text { Русское } \\
\text { название }\end{array}$ & Сечение, мм & Длина, м* & Объем, м \\
\hline Dobai & Ground sill & Нижний брус & $\begin{array}{c}105 \times 105 \\
(80-90 \%) \\
120 \times 120 \\
(10-20 \%)\end{array}$ & $\begin{array}{c}4,0,3,65 \\
3,0\end{array}$ & 0,8 \\
\hline Tsuka & Floor post & Опора лагов пола & $90 \times 90$ & Коротье & 0,2 \\
\hline Obiki & Girder & Балка пола & $\begin{array}{c}105 \times 105 \\
(80-90 \%) \\
90 \times 90 \\
(10-20 \%)\end{array}$ & $\begin{array}{c}4,0,3,65 \\
3,0\end{array}$ & 0,2 \\
\hline Neda & Floor joust & Лага пола & $\begin{array}{c}45 \times 45,45 \times 60 \\
60 \times 60,45 \times 105,45 \times 90\end{array}$ & $\begin{array}{c}4,0,3,65 \\
3,0\end{array}$ & 0,7 \\
\hline Toshibashira & Balloon post & Угловой опорный столб & $\begin{array}{l}105 \times 105 \\
120 \times 120\end{array}$ & 6,0 & 0,7 \\
\hline Kudabashira & Post & Опорный столб & $\begin{array}{l}105 \times 105(75 \%) \\
120 \times 120(25 \%)\end{array}$ & 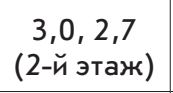 & 1,7 \\
\hline Mabashira & Middle stud & $\begin{array}{l}\text { Промежуточная стойка } \\
\text { (не опорная) }\end{array}$ & $\begin{array}{c}27 \times 105(70 \%) \\
30 \times 105(20-25 \%) \\
45 \times 105(5 \%) \\
30 \times 40(5 \%)\end{array}$ & 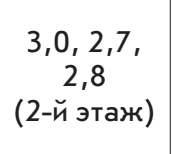 & 1,7 \\
\hline Sujikai & Diagonal wall brace & $\begin{array}{l}\text { Диагональная подпорка } \\
\text { стены }\end{array}$ & $30 \times 105,45 \times 90$ & 3,0 & 0,5 \\
\hline $\begin{array}{l}\text { Hirakaku**, } \\
\text { включая Hari }\end{array}$ & $\begin{array}{l}\text { Structural beam, } \\
\text { включая Tie beam }\end{array}$ & $\begin{array}{l}\text { Структурные балки, } \\
\text { включая анкерные } \\
\text { балки }\end{array}$ & $\begin{array}{c}120 \times 240 / 280 \\
105 \times 210,105 \times 180\end{array}$ & $\begin{array}{c}4,0(70- \\
80 \%), 3,0 \\
5,0,8,0\end{array}$ & 5,8 \\
\hline Keta & Top plate & Верхняя стеновая балка & $105 \times 105$ & 4,0 & 0,4 \\
\hline Koyazuka & Roof support post & Опора перекрытий & $105 \times 105$ & Коротье & 0,4 \\
\hline Moya & Purlin & Кровельная балка & $90 \times 90$ & 4,0 & 0,7 \\
\hline Munagi & Ride beam & Коньковая балка & $105 \times 105,90 \times 90$ & 4,0 & 0,1 \\
\hline Taruki & Rafter & Стропила & $30 \times 40,45 \times 45$ & $\begin{array}{c}4,0,3,8 \\
3,65\end{array}$ & 0,5 \\
\hline Прочие & - & - & - & - & 1,2 \\
\hline Итого & - & - & - & - & 15,6 \\
\hline
\end{tabular}




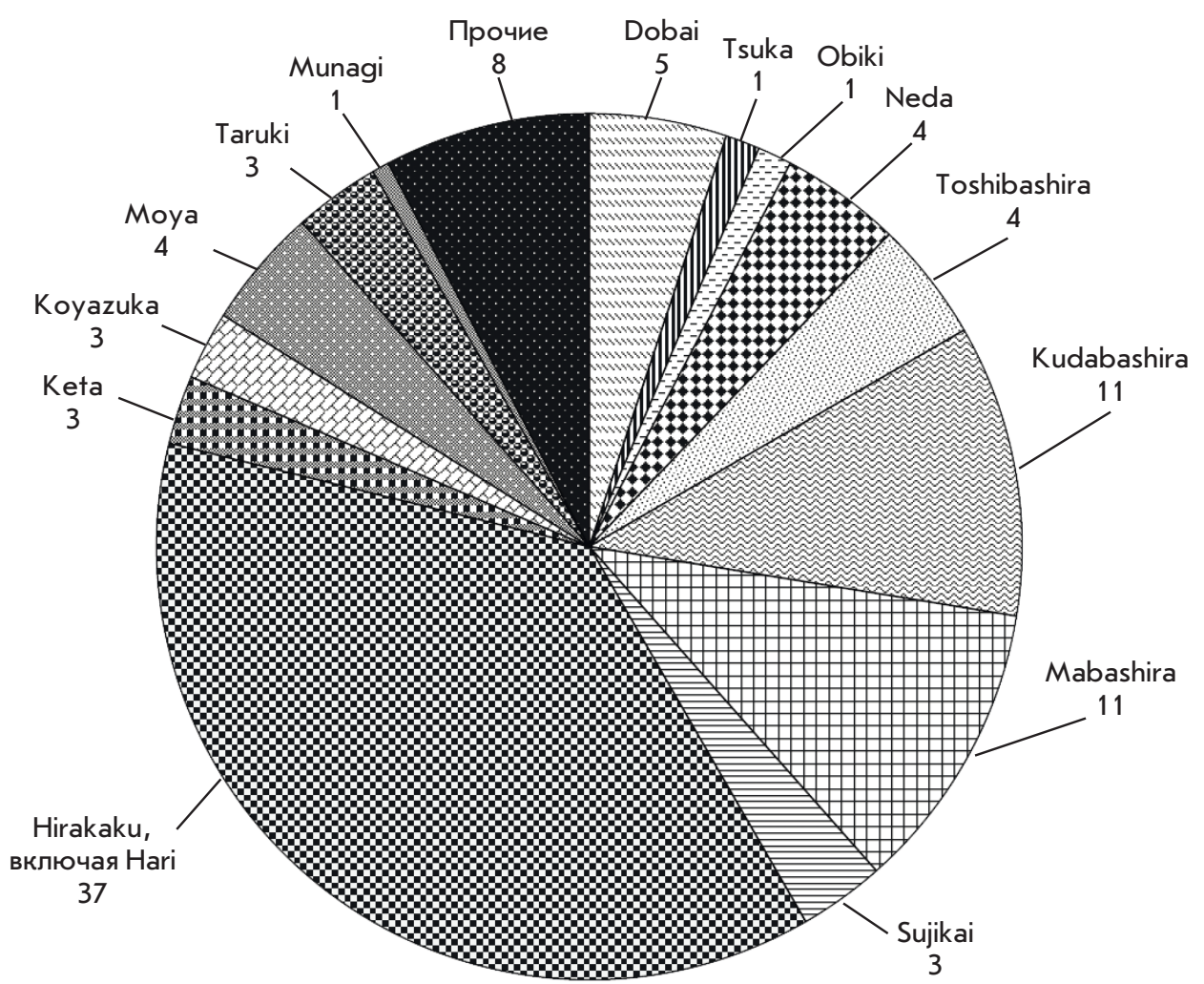

Рис. 2. Потребление древесины в компонентах традиционного японского дома, \%

Наибольший удельный вес в структуре потребления древесины в компонентах традиционного японского дома занимает hirakaku (включая hari) - $37 \%\left(5,8 \mathrm{~m}^{3}\right)$, mabashira и kudabashira - по $11 \%\left(1,7 \mathrm{~m}^{3}\right)$. Удельный вес taruki составляет около $3 \%\left(0,5 \mathrm{~m}^{3}\right)$.

Dobai - нижний брус дома, производится из сосны, основной размер - $105 \times 105$ мм $(80-90 \%)$ и $120 \times 120$ мм (10-20\%).

Tsuka - вертикальные опоры или стойки, которые переносят нагрузку сверху на горизонтальные конструктивные элементы под ними (или на землю), используемые для полов, колод или крыш.

Obiki - большие напольные балки, обычно сечением от 90 до 105 мм, которые простираются между основными балочными опорами. Obiki, как правило, отличаются от больших балок, которые стоят непосредственно на земле, называемых dobai, сечением.

Neda - балки перекрытия, типичные ceчения $30 \times 40 \mathrm{Mm}, 45 \times 45 \mathrm{мм} \mathrm{и} 45 \times 60 \mathrm{mм}$.

Toshibashira - единственная сплошная колонна, которая простирается от первого до второго этажа. Производится из сосны, основной размер - $105 \times 105$ мм.

Kudabashira - колонны, которые простираются от пола до потолка только одного этажа, в отличие от toshibashira, которые простираются от одного этажа до следующего над ним.

Mabashira - сухая строганая доска из еловой или сосновой древесины, обычно пиломатериал сечением $30 \times 105$ мм, используемый в качестве шпилек между основными столбами, стоящий не более чем на 455 мм от соседнего столба или шпильки, от центра к центру.

Sujikai - диагональная стеновая стяжка, обычно сечением $45 \times 90$ мм, закреплена на соседних столбах со специальным креплением и винтами.

Keta - термин, используемый для основных горизонтальных балок, стоящих в продольном направлении в верхней части hashiras (структурные колонны / столбы), которые поддерживают крышу конструкции. Хотя термин hari часто используется для обозначения всех горизонтальных балок, он технически относится к сравнительно коротким балкам, которые проходят перпендикулярно keta.

Hari (hirakaku) - крупные горизонтальные балки, проходящие перпендикулярно к keła, которые вместе составляют основную структурную поддержку второго этажа, а также любые последующие этажи выше, включая крышу. Балки hari и keta отличаются от бруса dobai тем, что 
расположены не на первом этаже или фундаменте.

Koyazuka - опора перекрытий, на которые крепится тоуа, производится из сосны, основной размер - $105 \times 105$ мм.

Моуа - горизонтальная кровельная балка, которая переносит грузы крыши на вертикальные столбы (koyazuka), обычно сечением $90 \times 90$ мм или $105 \times 105$ мм.

Munagi - коньковая балка $105 \times 105$ мм или $90 \times 90$ мм.

Taruki - это строганый брусок высокого качества из сосны камерной сушки. Изготавливается преимущественно из хвойных пород древесины. Taruki различных сечений применяется при строительстве домов в Японии и Корее. Брусок имеет различные размеры: $30 \times 40$ мм, $35 \times 35$ мм, $38 \times 38$ мм, $45 \times 60$ мм. На российском рынке taruki используется как строганый брусок для различных нужд. Лидером по изготовлению taruki является Канада [5, с. 225].

Также в японской строительной терминологии имеют место такие понятия, как dobuchi, nuki, sangi - строганые изделия высокого качества для японского деревянного домостроения. Нестроганой доской высокого качества из сосны естественной и камерной сушки является genban. Данная доска предназначена для дальнейшего производства готовой продукции непосредственно в Японии.

Далее рассмотрим количество начатых жилищных строительств по типам конструкций в Японии, которое представлено на рис. 3.

В настоящее время бо́льшая часть домов в Японии возводится из деревянных конструкций - на них приходится около
56-57 \% всех возводимых домов. Преобладание деревянного домостроения связано с устоявшимся мнением японского населения о том, что деревянные дома при землетрясении более устойчивы, чем металлические и другие конструкции.

Количество начатых жилищных строительств по типам конструкций в Японии в течение года колеблется от 68 до 88 тыс. ед., в том числе деревянное домостроение - от 38 до 51 тыс. ед. В структуре типов конструкций строящихся домов преобладает именно деревянное домостроение.

Необходимо отметить, что строительство деревянных домов в Японии подвержено сезонности. Снижение темпов строительства домов наблюдается в зимние месяцы (январь, февраль) - 38-39 тыс. ед., после чего происходит постепенное их увеличение - до 50-51 тыс. ед.

Объем производства пиломатериалов и древесных панелей в Японии ежегодно снижается. Правительство Японии стимулирует применение лесоматериалов, а также создание внутреннего интерьера из дерева в общественных зданиях, где только это возможно по строительным нормам. По данным Японской ассоциации строителей сборных домов, в планах правительства Японии в нежилом строительстве увеличение деревянного домостроения с $8 \%\left(\sim 870\right.$ тыс. м $\left.^{3}\right)$ в 2010 г. до $35 \%$ $\left(\sim 3900\right.$ тыс. м $\left.^{3}\right)$ в 2020 г.

Япония является одним из основных покупателей российских пиломатериалов. В табл. 2 представлены крупнейшие российские экспортеры хвойных пиломатериалов в Японию в 2016-2017 гг.

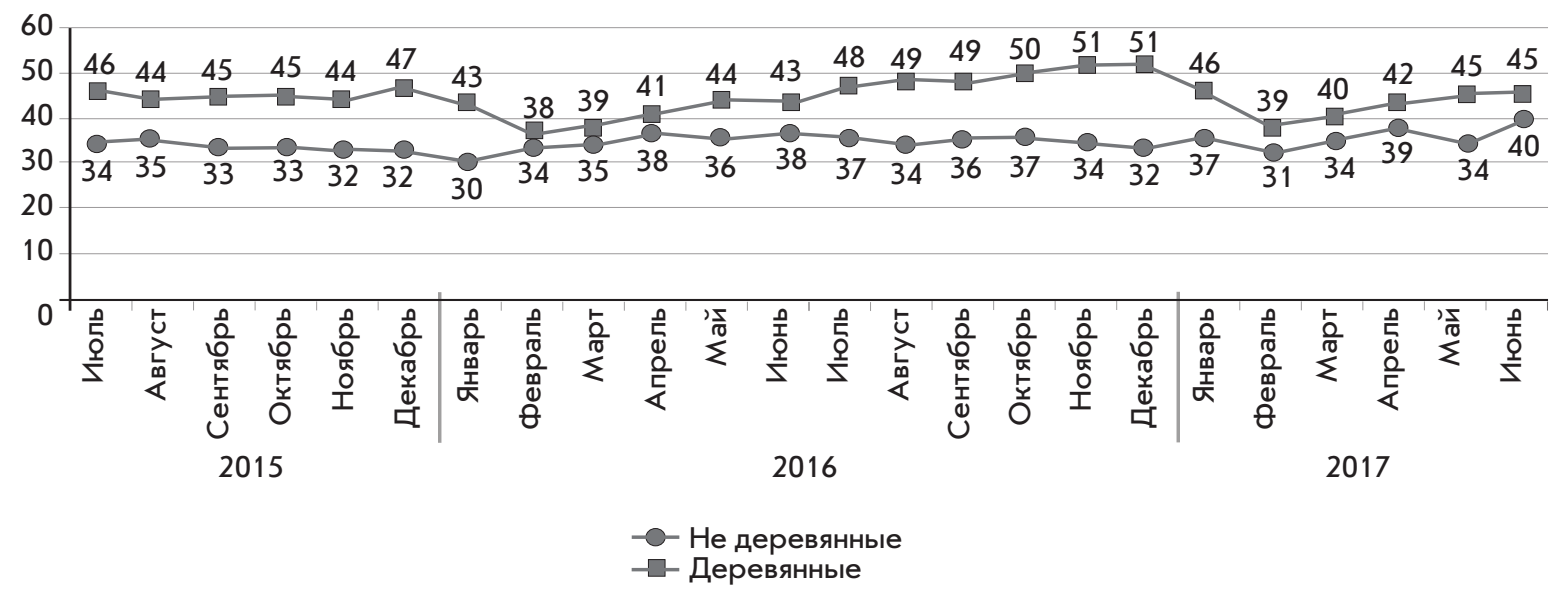

Рис. 3. Количество начатых жилищных строительств по типам конструкций в Японии, тыс. ед. Составлен по данным: Статистика рынка древесины в Японии. Начатое деревянное жилищное строительство в Японии. URL: http://www.jlj.gr.jp/database/hstarts.html 
Таблица 2

Крупнейшие российские экспортеры хвойных пиломатериалов в Японию в 2016-2017 гг., тыс. м³*

\begin{tabular}{|c|c|c|c|c|c|c|c|c|c|c|c|c|c|c|}
\hline \multirow{2}{*}{$\begin{array}{c}\text { Организации-экс- } \\
\text { портеры }\end{array}$} & \multicolumn{5}{|c|}{2016} & \multicolumn{9}{|c|}{2017} \\
\hline & $\begin{array}{c}\text { Ав- } \\
\text { густ }\end{array}$ & $\begin{array}{c}\text { Сен- } \\
\text { тябрь }\end{array}$ & $\begin{array}{c}\text { Ок- } \\
\text { тябрь }\end{array}$ & $\begin{array}{l}\text { Ho- } \\
\text { ябрь }\end{array}$ & $\begin{array}{c}\text { Де- } \\
\text { кабрь }\end{array}$ & $\begin{array}{c}\text { Ян- } \\
\text { варь }\end{array}$ & $\begin{array}{l}\text { Фев- } \\
\text { раль }\end{array}$ & Март & Апрель & Май & Июнь & Июль & $\begin{array}{c}\text { Ав- } \\
\text { густ }\end{array}$ & $\begin{array}{l}\text { Сен- } \\
\text { тябрь }\end{array}$ \\
\hline $\begin{array}{l}\text { ООО «Май- } \\
\text { ер-Мелнхоф Хольц } \\
\text { Ефимовский» }\end{array}$ & 10,3 & 8,7 & 10,0 & 12,0 & 8,6 & 10,2 & 6,7 & 7,6 & 4,5 & 13,2 & 17,3 & 14,5 & 14,4 & 16,0 \\
\hline ООО «ЛесРесурс» & 9,8 & 8,8 & 9,5 & 8,8 & 9,1 & 7,6 & 8,4 & 9,7 & 8,7 & 8,8 & 8,2 & 7,9 & 7,9 & 7,3 \\
\hline ООО «ТМ Байкал» & 4,2 & 1,3 & 1,9 & 8,4 & 7,8 & 6,2 & 7,3 & 7,0 & 7,5 & 5,8 & 6,6 & 7,8 & 8,3 & 6,5 \\
\hline ЗАО «ЛДК Игирма» & 4,1 & 1,6 & 2,5 & 3,3 & 3,5 & 2,8 & 3,3 & 3,8 & 3,2 & 3,5 & 4,0 & 4,2 & 2,2 & 3,0 \\
\hline $\begin{array}{l}\text { ООО «Русфрорест } \\
\text { Магистральный» }\end{array}$ & 3,8 & 3,4 & 3,6 & 4,6 & 4,3 & 3,6 & 3,5 & 3,6 & 3,2 & 3,4 & 3,1 & 2,8 & 2,4 & 2,5 \\
\hline $\begin{array}{l}\text { ИП Мамаев Евгений } \\
\text { Александрович }\end{array}$ & 4,1 & 3,6 & 4,2 & 3,8 & 3,4 & 0,0 & 0,0 & 0,0 & 0,0 & 0,0 & 0,0 & 0,0 & 0,0 & 0,0 \\
\hline ЗАО «Ката» & 2,9 & 2,6 & 3,0 & 3,2 & 3,6 & 3,1 & 3,9 & 4,3 & 3,8 & 4,2 & 3,3 & 2,5 & 2,5 & 3,0 \\
\hline $\begin{array}{l}\text { ООО «Амур } \\
\text { Форест» }\end{array}$ & 2,3 & 2,3 & 2,5 & 2,8 & 2,1 & 2,0 & 1,6 & 3,3 & 2,5 & 0,0 & 0,0 & 0,0 & 0,0 & 0,0 \\
\hline ООО «Азия Лес» & 0,0 & 0,0 & 0,0 & 0,0 & 0,0 & 0,0 & 0,0 & 0,0 & 0,0 & 0,0 & 0,0 & 0,0 & 0,0 & 0,0 \\
\hline ООО «Мется Свирь» & 4,3 & 2,5 & 2,6 & 2,6 & 0,2 & 1,1 & 2,9 & 1,3 & 2,4 & 1,0 & 2,1 & 1,9 & 2,8 & 1,7 \\
\hline $\begin{array}{l}\text { ООО «Леналес- } \\
\text { сервис» }\end{array}$ & 0,0 & 0,0 & 1,6 & 1,8 & 1,6 & 2,8 & 2,8 & 3,2 & 3,1 & 3,2 & 3,2 & 2,4 & 1,8 & 1,8 \\
\hline ООО «Илимпром» & 0,0 & 0,0 & 0,0 & 0,0 & 0,0 & 4,5 & 4,9 & 4,0 & 2,2 & 4,3 & 2,4 & 2,3 & 3,0 & 3,6 \\
\hline $\begin{array}{l}\text { ООО «ДОК } \\
\text { «Енисей» }\end{array}$ & 0,0 & 0,0 & 0,0 & 0,0 & 0,0 & 0,0 & 0,0 & 0,0 & 0,0 & 0,0 & 0,0 & 0,0 & 0,0 & 0,0 \\
\hline $\begin{array}{l}\text { ООО «Ангара } \\
\text { Плюс» }\end{array}$ & 2,2 & 2,0 & 1,6 & 1,8 & 0,0 & 0,0 & 0,0 & 0,0 & 0,0 & 0,0 & 0,0 & 0,0 & 0,0 & 0,0 \\
\hline Прочие & 24,8 & 25,7 & 20,8 & 24,7 & 36,8 & 27,6 & 27,2 & 35,8 & 34,0 & 37,6 & 32,1 & 27,8 & 27,1 & 22,1 \\
\hline Bcero & 72,8 & 62,5 & 63,8 & 77,8 & 81,0 & 71,5 & 72,5 & 83,6 & 75,1 & 85,0 & 82,3 & 74,1 & 72,4 & 67,5 \\
\hline
\end{tabular}

" Составлена по данным: Таможенная статистика внешней торговли // Федеральная таможенная служба : офиц. сайт. URL: http://www.customs.ru/index.php?id=13858\&ltemid=2095\&option=com_content.

В 2015 г. из России в Японию отгружено 846,9 тыс. м $^{3}$ хвойных пиломатериалов, в 2016 г. - 909,5 тыс. м (увеличение на 7,4\%), в 2017 г. - до 904,0 тыс. м³ (уменьшение на 0,6\%).

Крупнейшими российскими экспортерами хвойных пиломатериалов в Японию являются ООО «Майер-Мелнхоф Хольц Ефимовский» (Ленинградская область), которое экспортирует от 4,5 до 17,3 тыс. м $^{3}$ ежемесячно, ООО «Лес Ресурс» (Иркутская область) - от 7,6 до 9,7 тыс. М⿱3 , ООО «ТМ Байкал» (Иркутская область) - от 5,8 до 7,8 тыс. м². На долю первых трех крупнейших экспортеров хвойных пиломатериалов из России в Японию приходится более 30 \% всего объема поставок российской продукции в Японию $[6$, с. 70$]$.

Менее 5 тыс. м $^{3}$ хвойных пиломатериалов в месяц отгружают такие организации, как ЗАО «ЛДК Игирма», ООО «Русфорест
Магистральный», ИП Мамаев Е. А., ЗАО «Ката», ООО «Амур Форест», ООО «Азия Лес», ООО «Мется Свирь», ООО «ДОК «Енисей». Кроме представленных компаний, поставками хвойных пиломатериалов в Японию занимаются ЗАО «КрасноярскЛесоМатериалы» (Красноярский край), ООО «Русские пеллеты» (Свердловская область), Secure Intertrade ltd. (Иркутская о6ласть), ООО «Терра Сибирика» (Иркутская область) [7; 8; 9, с. 32] и другие компании [10, с. 11]. Бо́льшая часть экспортеров хвойных пиломатериалов сосредоточена в Иркутской области, которая располагает уникальными лесными ресурсами (здесь сосредоточено 12 \% запасов древесины спелых лесов страны) и обладает уникальными возможностями для строительства предприятий по глубокой переработке древесины [11-13; 14, с. 129].

Стоит отметить, что доставка хвойных пиломатериалов в Японию осуществляется 
преимущественно полувагонами до порта Находка, а далее на судах фрахтом через море. Часть сухой продукции отгружается контейнерами.

Основными покупателями хвойных пиломатериалов на японском рынке являются такие торговые дома, как Tairiku Trading, Itochu Kenzai, Sojits Building Materials, Sumitomo Forestry, Marubeni Building Materials, Emachu Mokuzai, Meiken, Japan Kenzai Holdings, Nice Corporation, Shinohara Shoten KK, Yoshimei, Yuasa Trading, Tajima, Kakumaru, Sakota, Hanwa, и другие торговые организации Японии.

Цена хвойных пиломатериалов на японском рынке формируется посредством спроса и предложения: когда отгрузочные порты, например порт Токио (единовременное хранение более 50 тыс. м $^{3}$ ), перезатарены, тогда происходит снижение цен на хвойные пиломатериалы (примерно на 10-20 дол. от цены) (рис. 4).

Цены на российские хвойные пиломатериалы в Японии продолжают расти по сравнению с рыночными ценами на внутреннем рынке страны. CIF-цена на строганый брусок (taruki) из сосны (ГОСТ 26002-83, сорт 1-2 (S), влажность (KD) 10-18\%, базис: порты Японии, $30 \times 40 \times 3985$ мм) в декабре 2017 г. составила 480 дол. за 1 м $^{3}$ (66 500 иен). По сравнению с январем 2017 г. цены на taruki выросли примерно на 2 \%.

Курс доллара по отношению к иене в течение 2017 г. постоянно колебался: в январе он составлял 114,9 иены за 1 дол., в декабре - 112,6. Курс доллара по от- ношению к российскому рублю в течение 2017 г. снизился: с 60,2 р. за 1 дол. в январе до 57,6 р. в декабре. В связи с этим производители экспортных пиломатериалов в Японию потеряли валютную выручку из-за снижения курса доллара, так как основной валютой при экспортных операциях является американский доллар $[15$, с. 71$]$.

Таким образом, исследовав потребление древесины в компонентах традиционного японского дома, проанализировав динамику экспорта хвойных пиломатериалов и цен на них в Японии, автор пришел к выводам:

1. В 2017 г. объемы экспорта хвойных пиломатериалов из России в Японию незначительно уменьшились - на 0,6 \% (до 904 тыс. $\mathrm{M}^{3}$ ).

2. Среди регионов отправки лидирует Иркутская область, которая экспортирует в Японию примерно половину всего объема пиломатериалов.

3. Основным покупателем хвойных пиломатериалов из России является Япония (около половины объема экспорта).

4. Основная категория экспорта обработанной древесины - строганые пиломатериалы из сосны.

5. В структуре типов конструкций строящихся домов в Японии преобладает деревянное домостроение (56-57\%).

6. Наибольший удельный вес в структуре потребления древесины в компонентах традиционного японского дома занимает hirakaku (включая hari).

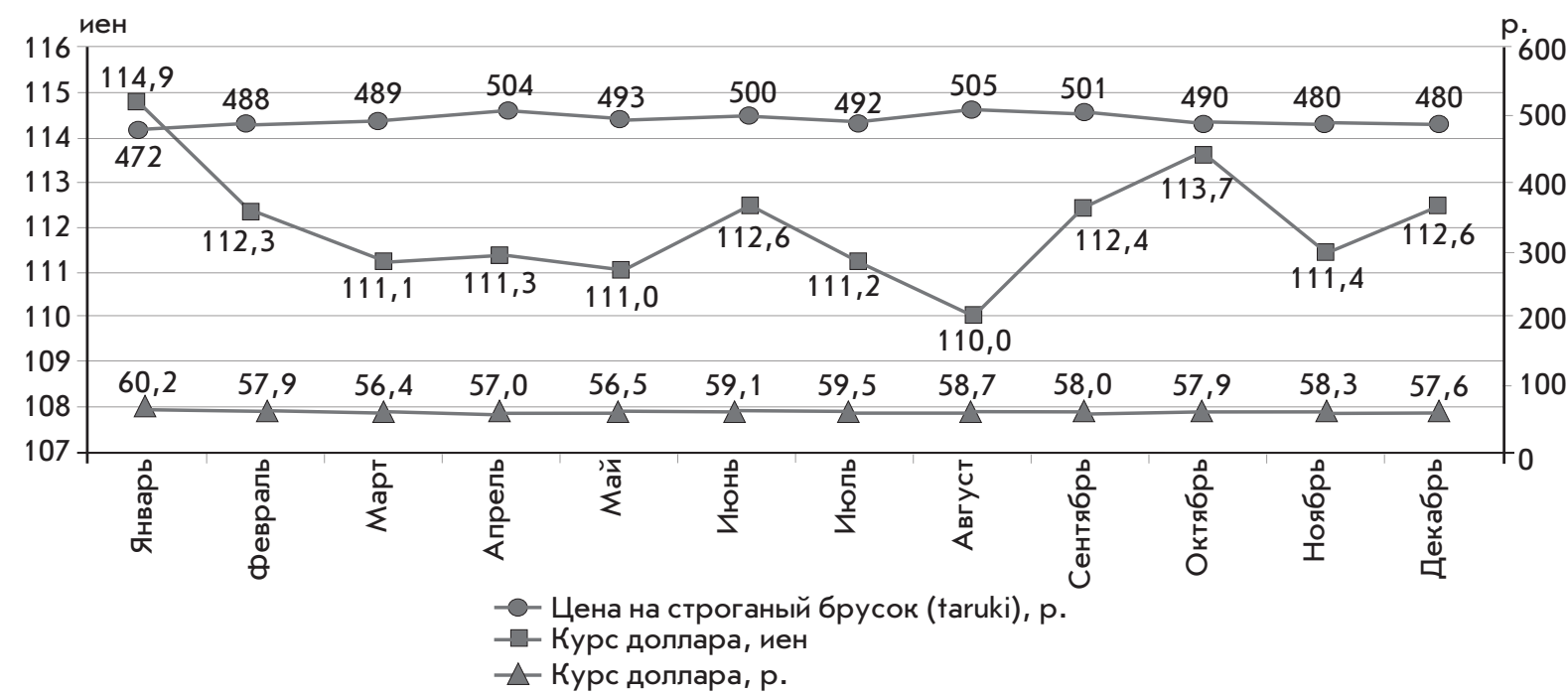

Рис. 4. Цена на строганый брусок (taruki) в 2017 г., сосна, гОСт 26002-83, сорт 1-2 (S), KD 10-18\%, базис: порты Японии, 30 × 40 × 3 985, курс рубля к доллару и курс иены к доллару (на конец месяца)

Составлен по данным Центрального банка Российской Федерации (URL: http://www.cbr.ru) 


\section{СПИСОК ИСПОЛЬЗОВАННОЙ ЛИТЕРАТУРЫ}

1. Варламова Н. Н. Лесной комплекс Дальнего Востока: перспективы сотрудничества со странами Северо-Восточной Азии / Н. Н. Варламова // Россия и Китай: новый вектор развития социально-экономического сотрудничества : сб. тр. 2-й междунар. науч.-практ. конф. - Благовещенск : Изд-во Амур. гос. ун-та, 2013. — C. $192-196$.

2. Пугоев Б. А. Проблемы современного российского лесного рынка / Б. А. Пугоев, О. А. Николайчук // Бенефициар. - 2017. - № 15. - С. 32-35.

3. Суровцева Л. С. Новый рынок сбыта пилопродукции / Л. С. Суровцева, О.С. Козаченко // Электронный научный журнал. - 2016. - № 4 (7). - С. 164-168.

4. Цыбинова Е. М. Анализ тенденций развития европейского рынка пиломатериалов / Е. М. Цыбинова, А. В. Новикова, Л. П. Андреева / / Актуальные проблемы лесного комплекса. — 2015. - № 42. - С. 89-92.

5. Кузичкин А. С. Становление и развитие качества производства пиломатериалов в Российской Федерации / А. С. Кузичкин, В. В. Левшина / / Молодежь Сибири - науке России : сб. тр. междунар. науч.-практ. конф. - Красноярск : Изд-во Сибир. ин-та бизнеса, упр. и психологии, 2014. - С. 225-228.

6. Коробченко А. В. Перспективы развития рынка пиломатериалов в Иркутской области / А. В. Коробченко / / Российская экономика в современных условиях : сб. ст. / под ред. В. П. Горева. - Иркутск : Изд-во БГУ, 2015. - С. 70-74.

7. Лесопользователи Иркутской области : свидетельство о гос. регистрации базы данных № 2018620541 от 10 апр. 2018 г. : заявка № 2018620220 от 26 февр. 2018 г. / А. П. Суходолов, А. В. Новиков ; заявитель и правообладатель ФГБОУ ВО «БГУ».

8. Иконников В. Российский рынок экспортных пиломатериалов / В. Иконников / / ЛесПромИнформ. 2017. - № 3 (125). - С. 22-25.

9. Новиков А. В. Предприятия и организации лесного комплекса Иркутской области / А. В. Новиков // Формирование и развитие биосферного хозяйства : сб. материалов 5-й междунар. науч.-практ. конф. - Иркутск : Оттиск, 2015. - С. 32-39.

10. Мясников Д. А. Проблемы теневой экономики в лесопромышленном комплексе Иркутской области: особенности исследования и оценки / Д. А. Мясников / / Известия Иркутской государственной экономической академии. - 2006. - № 6. - С. 11-13.

11. Суходолов А. П. Лесные ресурсы Сибирского федерального округа: эффеективность использования / А. П. Суходолов / / Ресурсы регионов России. - 2001. — № 5. - С. 30-37.

12. Суходолов А. П. Целлюлозно-бумажная промышленность Байкальского региона: история, экологоэкономические проблемы, перспективы развития / А. П. Суходолов. - Новосибирск : Изд-во Ин-та экономики и орг. пром. пр-ва, 1995. - 144 с.

13. Хамаганова Л. Д. Пути повышения эфффективности экспорта российских лесоматериалов / Л. Д. Хамаганова / / Известия Иркутской государственной экономической академии. - 2008. - № 5 (61). - С. 82-87.

14. Чаликова-Уханова М. В. О возможностях развития глубокой переработки лесных ресурсов в Иркутской области / М.В.Чаликова-Уханова / / Известия Иркутской государственной экономической академии. 2009. - № 4 (66). - С. 128-131.

15. Кривокоченко Л. В. Конъюнктура мирового рынка лесоматериалов и перспективы развития российского экспорта / Л. В. Кривокоченко / / Российский внешнеэкономический вестник. — 2016. — № 2. - С. 71-81.

\section{REFERENCES}

1. Varlamova N. N. Timber Industry of the Far East: Perspectives of Cooperation with North East Asia Countries. Rossiya I Kitai: novyi vector razvitiya sotsialno-ekonomicheskogo sotrudnichestva. Materialy 2-i mezhdunarodnoi nauchno-prakticheskoi konferentsii, Blagoveshchensk, 2013 g. [Russia and China: a New Direction of Social Economic Cooperation Development. Materials of $2^{\text {nd }}$ International Research Conference, Blagoveshchensk, 2013]. Blagoveshchensk, Amur State University Publ., 2013, pp. 192-196. (In Russian).

2. Pugoev B. A., Nikolaichuk O. A. Issues of Contemporary Russian Timber Market. Benefitsiar = Beneficiary, 2017, no. 15, pp. 32-35. (In Russian).

3. Surovtseva L. S., Kozachenko O. S. A New Market of Sawn Timber. Elektronnyi nauchnyi zhurnal=Electronic Journal, 2016, no. 4 (7), pp. 164-168. (In Russian).

4. Tsybinova E. M., Novikova A. V., Andreeva L. P. Analysis of Development Trends of the European Sawn Wood Market. Aktualnye problemy lesnogo kompleksa = Topical Issues of Timber Industry, 2015, no. 42, pp. 89-92. (In Russian).

5. Kuzichkin A. S., Levshina V. V. Formation and Quality Development of Sawn Wood Production in the Russian Federation. Molodezh Sibiri - nauke Rossii. Materialy mezhdunarodnoi nauchno-prakticheskoi konferentsii, Krasnoyarsk, 2014 g. [Youths of Siberia for Russian Science. Materials of International Research Conference, Krasnoyarsk, 2014]. Krasnoyarsk, Siberian Institute of Business, Management and Psychology Publ., 2014, pp. 225-228. (In Russian).

6. Korobchenko A. V. Development Perspectives of Sawn Wood Market in the Irkutsk Region. In Gorev V. P. (ed.). Rossiiskaya ekonomika v sovremennykh usloviyakh [Russian Economy in the Current Situation]. Irkutsk, Baikal State University Publ., 2015, pp. 70-74. (In Russian).

7. Sukhodolov A. P., Novikov A. V. Lesopol'zovateli Irkutskoi oblasti. Svidetel'stvo o gosudarstvennoi registratsii bazy dannykh № 2018620541 of 10 aprelya $2018 \mathrm{~g}$. Zayavka № 2018620220 of 26 fevralya $2018 \mathrm{~g}$. Zayavitel' i pravoobladatel' FGBOU VO «BGU» [Timber Producers of the Irkutsk Region. Certificate of Database Registration № 2018620541, April 10, 2018. Application № 2018620220, February 26, 2018. Applicant and Titleholder FSBEI of Higher Education «Baikal State University»]. 
8. Ikonnikov V. Russian Market of Export Sawn Wood. LesPromInform = Timber Industry Bulletin, 2017, no. 3 (125), pp. 22-25. (In Russian).

9. Novikov A. V. Timber Industry Enterprises and Companies of the Irkutsk Region. Formirovanie i razvitie biosfernogo khozyaistva. Materialy 5-i mezhdunarodnoi nauchno-prakticheskoi konferentsii [Formation and Development of Biosphere Industry. Materials of $5^{\text {th }}$ International Research Conference]. Irkutsk, Ottisk Publ., 2015, pp. 32-39. (In Russian).

10. Myasnikov D. A. Problems of shadow economy in a timber industry complex of Irkutsk region: features of research and estimation. Izvestiya Irkutskoi gosudarstvennoi ekonomicheskoi akademii = Izvestiya of Irkutsk State Economics Academy, 2006, no. 6, pp. 11-13. (In Russian).

11. Sukhodolov A. P. Timber Resources of Siberian Federal District: Utilization Efficiency. Resursy regionov Rossii = Resources of Russian Regions, 2001, no. 5, pp. 30-37. (In Russian).

12. Sukhodolov A. P. Tsellyulozno-bumazhnaya promyshlennost Baikalskogo regiona: istoriya, ekologo-ekonomicheskie problemy, perspektivy razvitiya [Pulp and Paper Industry of the Baikal Region: History, Environmental Economic Issues, Development Perspectives]. Novosibirsk, Institute of Economics and Industrial Engineering Publ., 1995. $144 \mathrm{p}$.

13. Khamaganova L. D. Ways of increase of efficiency of export of the Russian commercial timbers. Izvestiya Irkutskoi gosudarstvennoi ekonomicheskoi akademii = Izvestiya of Irkutsk State Economics Academy, 2008, no. 5 (61), pp. 82-87. (In Russian).

14. Chalikova-Ukhanova M. V. Speaking about possibilities of deep wood processing development in Irkutsk region. Izvestiya Irkutskoi gosudarstvennoi ekonomicheskoi akademii = Izvestiya of Irkutsk State Economics Academy, 2009, no. 4 (66), pp. 128-131. (In Russian).

15. Krivokochenko L.V. World timber markets: state and prospects for Russia's exports. Rossiiskii vneshneekonomicheskii vestnik = Russian foreign economic journal, 2016, no. 2, pp. 71-81. (In Russian).

\section{Информация об авторе}

Новиков Александр Викторович - кандидат экономических наук, магистрант, кафедра экономики и управления бизнесом, Байкальский государственный университет, 664003, г. Иркутск, ул. Ленина, 11, e-mail: novirk@ya.ru.

\section{Для цитирования}

Новиков А. В. Экспорт хвойных пиломатериалов из России в Японию / А. В. Новиков // Известия Байкальского государственного университета. - 2018. - T. 28, № 2. - C. 275-283. - DOI: $10.17150 / 2500-2759.2018 .28(2) .275-283$.

\section{Author}

Alexander V. Novikov - Ph.D. in Economics, graduate student, Department of Economics and Business Management, Baikal State University, 11 Lenin St., 664003, Irkutsk, the Russian Federation, e-mail: novirk@ya.ru.

\section{For citation}

Novikov A. V. Softwood Lumber Exports from Russia to Japan. Izvestiya Baykal'skogo gosudarstvennogo universiteta $=$ Bulletin of Baikal State University, 2018, vol. 28, no. 2, pp. 275-283. DOI: 10.17150/2500-2759.2018.28(2).275-283. (In Russian). 